The Review of Education, Pedagogy,

and Cultural Studies, 26: 129-153, 2004

Copyright (C) Taylor \& Francis Inc.

ISSN: $1071-4413$ print

DOI: $10.1080 / 10714410490480386$

\title{
Cultural Studies in Turkey: Education and Practice
}

\section{Gönül Pultar and Ayşe Lahur Kırtunç}

It would be difficult to pinpoint when the instruction of cultural studies began in Turkey, as humanities and social science scholars with ties to academic circles in various parts of the world where cultural studies has been practised reflected the methodology in the various courses they taught as soon as they themselves became acquainted with it. The Crossroads in Cultural Studies conference, begun in 1996 in Tampere, has counted from its very inception numerous participants from Turkey. It must be said that cultural studies seems to have been invented especially for Turkish society, as its emphasis on examining issues of power and social difference makes it a particularly apt approach to exploring and critiquing the decidedly hierarchical and patriarchal character of the latter. Turks from different walks of life who have suffered since childhood at the hands of overbearing parents, instructors, bosses and officials almost need no explanation when exposed to Michel Foucault: his work reflects and speaks to their experience. Moreover, in this age of globalization and translocation, the positionality of the Turks in the global village as subjects (in both the sense of active agents and being subjected to various discourses and institutions) is best contextualized in and explored through the multi-faceted and interdisciplinary discourse of cultural studies. The social science student who investigates the predicament of the Gastarbeiter's mistreatment at the hands of the German Polizei or Meister finds in cultural studies an elucidation no single, discrete discipline affords. Cultural studies likewise unfolds, for the student of literary studies reading the emerging Turco-German authors such as Renan Demirkan ${ }^{\mathrm{i}}$ and Emine Sevgi Özdamar, ${ }^{\mathrm{ii}}$ a fascinating narrative of immigration and ethnic identity formation which eludes traditional literary analysis. ${ }^{\text {iii }}$ A society that has suffered for centuries in 
the grips of Orientalism, both explicit and implicit, identifies with each and every line of Edward Said's brilliant exposé (1978) and regrets only that one of its members did not pen it. Therefore, in an educational system within which disciplines are rigidly departmentalized and compartmentalized, cultural studies, before emerging as a specific program in various universities in the late nineties and since, was being taught as an approach and a complement in various courses in various fields.

This essay aims at contributing to the debate on "International Perspectives on Cultural Studies in/and Education" by presenting a perspective from Turkey, and problematizing the issues that are encountered in the country in the instruction and practice of cultural studies. We start with a brief survey of the Ege University Cultural Studies Symposium which launched in 1995 the first formal manifestation of cultural studies in the country. We then review the cultural studies departments, both graduate and undergraduate, that have been established in various universities. This is followed by an examination of the activities of the inter-university Group for Cultural Studies in Turkey. Finally, we discuss questions emerging for educators and practitioners of cultural studies in Turkey and argue that these constitute hurdles that need to be overcome for the proper institution of this interdisciplinary approach in this poly-cultural nationstate.

\section{THE EGE UNIVERSITY CULTURAL STUDIES}

Cultural studies formally made its debut in Turkey when Ege University (Izmir) hosted the country's first cultural studies conference, which has since become an annual conference held every May. As cultural studies first began in the West, albeit with the assistance of non-Western theorists, it is only natural that it should be scholars of a Western culture and civilization who initiated the project of establishing cultural studies in Turkey. Indeed, it all began when a small group of Americanists (that included both authors of this article) decided to organize a miniconference on what today would be called, more specifically, American ethnic studies. (Interestingly enough, although cultural studies traces its origins to the UK, the Anglicists in Turkey lagged behind their Americanist colleagues in following the latest paradigm changes.) Thus, what is now known as Ege University Cultural Studies Symposium (http://css.ege.edu.tr) started as a two-day event co-organized by the Department of American Culture and Literature of 
Ege University and the American Studies Association of Turkey. It took place on April 10-11, 1995 and was entitled "The Red, Black and White." Five scholars presented papers and films on many aspects of the Native Americans and African Americans. It was attended by the students and faculty of Ege University and Dokuz Eylül University (Izmir).

The following year, the Symposium was announced widely and the number of participants increased to 150 . What was more noteworthy was that five different units or institutions now collaborated on its organization. The Department of English Language and Literature of Ege University joined the American Studies Association of Turkey and the Department of American Culture and Literature of Ege University as co-organizer, while the United States Information Service (which has become the Cultural Office of the US Embassy since) and the British Council in Ankara rivaled for sponsorship. This last collaboration was notable first because it was the first time that these two institutions had participated in a joint project, and secondly because the collaboration came at a time when the two institutions were competing for the allegiance ${ }^{\mathrm{iv}}$ of Turkey's English-speaking academics and students. ${ }^{\mathrm{v}}$ The Symposium thus very quickly developed into a huge conference which included not only American but also British, and finally and inevitably, Turkish themes. Soon this conference taking place in the month of May on the Aegean coast was being noticed and acknowledged by scholars from across the globe.

Thus, the Symposium continued to grow over the years and become more international. It has always been a venue where young academics could present their work alongside prominent names. From the first day on, the aim of the Symposium was to contribute to the establishment of cultural studies within Turkey. It was hailed as a significant milestone by those academics in the humanities and social science departments in Turkey who were cognizant of the cultural studies turn, and became a platform where inter- or multidisciplinary approaches to such subjects as literature, history, media studies and sociology could be explored. It has since become an event that brings together professionals, academics, artists, writers and students to share views on that year's designated theme. Open to all cultural studies topics, it serves as a forum for debate allowing international scholars to acquaint themselves with cultural studies work being done in Turkey, and Turkish scholars to keep abreast of the latest developments in the field. Education and pedagogy have been themes addressed with presentations that have generated heated debates on curriculum, methodology and ideology. 
Some of these debates have gone beyond the discussion of the presentations themselves and became an arena where the so-called traditionalist and progressivist ideologies clashed with unforeseen force and stamina. The traditionalist side was for upholding the methodology and curricula of single disciplines, mostly because they were trained that way and were unwilling to invest in retooling let alone giving up their gatekeeping positions in academia. The progressivist side was uneasy about being too iconoclastic too soon because the price for academic "disrespect," as it was seen to be, traditionally ranged from being blacklisted to being refused academic promotion. The first "Culture Wars" in Turkey, it must be said, were fought within academia. Studying them and their impact on the trajectory of the instruction and establishment of cultural studies in Turkey remains - a cultural studies task.

The papers presented during the Symposia were published by the British Council and the American Studies Association of Turkey in the early years, and are now being published by Ege University. ${ }^{\mathrm{vi}}$ The Symposium and the proceedings have been a valuable contribution to the effort of establishing cultural studies within academic curricula in Turkish universities.

It must be noted that apart from being a venue where new, inspiring and controversial ideas are discussed and evaluated, the Symposium has contributed significantly to providing a model in collaboration patterns in academia: the organization has necessitated the honing of such skills as could be a checklist of some of the dos and don'ts of cultural studies. Also, the Symposium has featured numerous concerts, dance, film and theater performances, as well as photography and art exhibits by international artists who have enhanced the interdisciplinary and praxis character.

The more consequential effect of the Ege University Cultural Studies Symposium has been the gradual change in the curriculum of the Department of American Culture and Literature at Ege University. There has been a twofold change: the courses and course contents changed over the years to reflect what had been happening during the Symposia; courses related to media, history, art, economics and international relations have been incorporated into the traditional, literature-based program. Even the literature courses changed to reflect the thematic approach of the culture courses and began to utilize methodology that went beyond traditional (including contemporary) literary theory. ${ }^{\mathrm{vii}}$ The second gain has been registered through the response of the students: having been exposed to the eclectic approach of cultural studies, they were able to transfer the skills they used in "reading" non-linear texts to interpreting literature. Courses in 
semiotics and film study resulted in the students' awareness that they could use the same skills in deconstructing and analyzing cultural products for texts that were not part of their curriculum. This meant a significant improvement in the critical thinking abilities of the students.

\section{CULTURAL STUDIES PROGRAMS}

Four universities in Turkey have so far instituted cultural studies programs - although of course, various courses that would fall under the rubric of cultural studies are being taught in various departments of various other universities, while other departments are being affected and/or altered by the cultural studies turn, as discussed above. There is one undergraduate program at Sabancı University, and graduate programs at Bilgi, Boğaziçi, and Middle East Technical universities. These are briefly discussed below to give a feel of cultural studies instruction in Turkey.

\section{An Undergraduate Program: The Sabancı University Cultural Studies Program}

Sabanc1 University (Istanbul) offers its undergraduate students courses in cultural studies as part of a humanities program, ${ }^{\text {viii }}$ located in the Faculty of Arts and Social Sciences. Established in 1999, Sabanc1 University has an institutional structure based, not on the traditional department system, but on the idea that faculties should interact educationally. Therefore, the Cultural Studies courses are offered to all students who have a primary or secondary interest in social sciences and/or humanities. On the university's website, http:/www.sabanciuniv.edu.tr/english/ index 1.html, the aim of this undergraduate program is presented thus:

The Cultural Studies Program is a multidisciplinary field of study that combines the strengths of the social sciences and the humanities, drawing on methods and theories from disciplines such as Anthropology, Literary Studies and Visual Studies. The Program aims to equip students with the scholarly tools, practices and ethics required for cultural analysis. This involves addressing the critical relations between culture, power, history and identities, as well as investigating the production, reception and use of contemporary cultural products. Locating Cultural Studies in the context of Turkey constitutes an important emphasis of the Program (accessed 19 June 2003). 
Focusing on such thematic areas as "Politics of Culture, Cultural and Literary Theory, Popular Culture, Gender, and Space/Time," the program contains variously named courses on theory and methodology emanating from the West and incorporating the ideas of the major gurus. It also features such courses as "East/West Encounter," that is "a critical review of texts, images and institutional-scholarly discourses that reflect or embody the East/West problematic"; "War and Literature in Turkish History," which analyzes "Turkish narratives or echoes of the Balkan Wars, World War I, the War of Independence, World War II, the Korean War," and so forth, and discusses "the question of just and unjust wars"; "Turkish Culture: Critical Perspectives," which discusses what "Turkish culture" is; "Popular Culture in Contemporary Turkey"; "Gender and Sexuality in the Middle East," organized around the question of "How is masculinity/femininity defined, practiced, and discussed in different Middle Eastern societies such as Iran, Egypt, Syria, Israel, Palestine, Turkey, and Jordan?" as well as topics such as "male circumcision, female genital mutilation, feminist movements, clothing and veiling, domestic violence, virginity controls," and "women's participation in nationalist politics and wars, as well as the connections between masculinity, national identity, and soldiering"; "Gender and Sexuality in Turkey" exploring issues such as "the evolution of the feminist movement from the late nineteenth century till today, the experiences and narratives of masculinity, violence against women, virginity debates, the interconnections between gender and nationalism, religious and state discourses on the body, the politics of secularism and Islam"; "Modern Turkish Literature" discussing "the repercussions of social and political movements in Turkish literature," and such issues as representations of national identity, not only by Turkish authors writing in Turkish, but also in English, such as Halide Edib; "Turkish Social Thought" dealing with the basic social and political ideas developed in the early republican period in Turkey and since, with a "special emphasis" on "'essential' conflictual concepts, such as East-West, modernity-conservatism," as well as with basic schools of thought in Turkey and the ideas and arguments of the prominent thinkers and intellectuals of the country" (http://www.sabanciuniv.edu.tr/english/index1.html, accessed 19 June 2003).

\section{Graduate Programs: The MA program in Cultural Studies at Bilgi University}

Inaugurated in 1999, the MA program in Cultural Studies at Bilgi University (Istanbul) is an eclectic collection of courses ranging from general ones on cultural theory and analysis to more 
specific ones related to historiography, literature and sociology. On close scrutiny, the ambitious program offers the same challenge as the one posed by cultural studies itself: to design a roadmap of study, which ultimately provides a focus of some kind.

On Bilgi University’s website, http://www.bilgi.edu.tr/graduate/MAindex.htm\#10 (accessed 18 June 2003), the MA program in Cultural Studies is described as being

an interdisciplinary programme offering courses in communication studies, film and TV studies, history, literary theory, philosophy, political science, and sociology. The programme is designed to develop a comparative, multidisciplinary approach to the analysis of maps of meaning in the contemporary world. As a graduate programme taught by international and Turkish specialists in various fields, the MA in Cultural Studies aims to systematically study the asymmetrical relationships among various social groups and identities which create and are created by these maps of meaning. Offering a wide range of courses, the programme sets out not to provide just an educational environment but to create a community of researchers consisting of faculty members and students.

This program also contains the basic courses, yet with allusions in most cases to the Turkish situation. Besides these, the program also includes such courses as "Studies on Culture in Contemporary Turkey I-II," which concentrates on "the processes in which the nation state was established and national literature came into existence in Turkey"; "Reorienting East and West from the Middle," which "considers various modes of imagining the other," with "a special focus on Turkey," which "has debated how to place itself between a world of the East, one of past riches and glories, and a world of the West, one of modernity"; "Making Sense of the Past: Constructions of Ottoman-Turkish Historiography," which analyzes "the new historical discourses that successive generations of Ottoman-Turkish historians developed throughout the late nineteenth and early twentieth centuries, especially on the "Ottoman-Turkish modernization," in the light of the political debates of their time"; "Westernization or Modernization? Ottoman Empire in the Eighteenth and Nineteenth Centuries," with the "modernizing movements in the eighteenth and nineteenth centuries and their impact on Ottoman art and culture" as the main theme of this course. Finally, "Studies in Cultural Diversity I-II" aims "to study the multicultural demographic topography of Turkey on a historical, sociological and cultural background." What have the ethnicities, which have inhabited this geography, experienced throughout history? How did they contribute to the cultural patrimony of Anatolia? 
What problems have been faced at what points in the country's history? These are examples of the sorts of questions being posed and addressed in this and the other courses of the program.

\section{The Boğaziçi University MA Program in Critical and Cultural Studies}

Boğaziçi University (Istanbul) also has an MA program in Critical and Cultural Studies (http://www.boun.edu.tr/graduate/index tur.html), begun in the fall of 2002, which focuses on contemporary cultural and critical theories. ${ }^{\text {ix }}$ Along with the typical methodology and research courses, the program incorporates elective courses from social sciences and the humanities, and is engineered to provide an interdisciplinary and cross-cultural grid on which to tack such issues as productions of cultural meanings and identities and definitions of culture.

This program aims

to offer students the theoretical and analytical tools with which to read culture critically. It is designed to enable them to analyze a wide range of cultural texts and practices in the light of contemporary cultural and critical theories. It also allows each student to pursue his/her particular interest within an interdisciplinary and cross-cultural frame" (E-mail message from program coordinator to the authors, 4 June 2003).

Unlike Sabanc1 University, which started in 1999, and Bilgi University, which started in 1996, Boğaziçi University is more than a century old. Its history goes back to 1863 , when it was founded as Robert College, the first American institution of higher learning to be established outside of the US. It was turned over to the Turkish government in the early 1970s, which shaped it as a state university, retaining English nevertheless as the medium of instruction. Thus, unlike the other two universities, both private, which, however ambitious they may be academically, have yet to prove themselves, Boğaziçi boasts of a tradition of great learning and scholarship that has always been supported by a faculty of high caliber. Consequently, the courses "in a related field," as they put it, that the program is able to offer to its students, especially in West-based knowledge, is impressive and abundant - too abundant to be listed. However, the task of drawing a roadmap falls on the student, as most of the electives that the departments servicing the program are able to propose to the students do not, as a matter of course, adopt a cultural studies approach. "Ottoman Intellectual History (Nineteenth-Twentieth Century)"; "Seminar in Social and Economic History of Byzantium"; "The Art and the Archaeology of the Ancient Near East through the Classical Period"; "The Turkish Novel and Short Story From the Tanzimat to the 
Republican Period"; "The Turkish Folk Story"; "Traditional Turkish Theater" are some such courses.

\section{The Media and Cultural Studies (MCS) Graduate Program at METU}

The graduate program in Media and Cultural Studies (MCS) at Middle East Technical University (Ankara), known by its acronym METU, was started in the fall of 2002, and is, according to the information given on the university's website (http://www.metu.edu.tr/home/wwwsbe/MCS/ info.htm):

an interdisciplinary framework for studying the relations between media and culture in the complex and changing context of contemporary societies. As with most graduate programmes, the emphasis is on the development of intellectual mastery as well its interconnections with professional competence in the information era.

The graduate Programme in Media and Cultural Studies aims to relate contemporary Theory and criticism to mass mediated communications and culture and focuses on issues such as mass culture, popular culture, visual culture, commodification of culture, globalization, cultural identity, gender and subculture, media economics, media power, influence and effects, new communication technologies, normative, legal and ethical issues in media, visual representation (accessed 19 June 2003).

The program, which allows for thesis and no-thesis options, "draws its main disciplinary resources and academic strengths from METU's departments of History, Political Science and Public Administration, Philosophy and Sociology." METU was established in the 1950's by the Turkish government as an English-medium university targeting a studentship from the whole region of the Middle East. It enjoyed a copious international grant that allowed it to invite scholars of worldwide renown, which immediately set it as one of the best universities in the country. It has remained so, and thus "students benefit from METU's tradition of academic excellence," as the program description itself has it, "through shared teaching across a number of optional courses alongside MCS courses." These include courses offered by METU's Graduate School of Informatics, and METU's Audiovisual Systems Research and Production Center (GISAM), with its technical facilities at broadcast level as additional assets for MCS.

As its focus on media requires, the program contains such courses as "Sociology of Journalism" or "Philosophy of Communication" besides the variously named, basic courses, with 
a special emphasis on communication, on theory and on methodology. "Communications Policy in Turkey" and "History of Ottoman Press and Publications" are among the other courses offered.

As this essay is being written (June 2003), none of the four programs have produced any graduates. They are of course still in their infancy, undergoing a trial and error period, accompanied by much discussion and reflection, as reported verbally to the authors, that hopefully will yield in the future substantial cultural studies work done in Turkey. So any evaluation of these programs is premature, except to remark that the initiators deserve to be lauded for their efforts to implement cultural studies in Turkey. However, some observations are in order. Although differences among the four programs are readily discernible, one common trait, beyond the shared goal of teaching and promoting cultural studies, is their medium of instruction (i.e., the English language). This is seen to carry its own modality: although there are original cultural studies courses on Turkey and Turkish culture, as can be seen in the programs discussed above, it would not be wrong to advance that the overall objective is training the students in the theories of the major figures of Anglo-centric cultural studies (with that of the ubiquitous French as part of its corpus) to allow them to "perform," namely, do research, teach, participate, in the international academic arena, as masterfully as all other international scholars.

\section{THE GROUP FOR CULTURAL STUDIES IN TURKEY}

The group of academics from different universities (again with both authors among them) ${ }^{\mathrm{x}}$ who convened in Ankara on 16 October 1999 to establish what was to become the Group for Cultural Studies in Turkey (Türkiye Kültür Araştırmaları Grubu in Turkish) knew that for cultural studies to take root in Turkey, it needed to be practiced primarily in Turkish, and also have a Turkish focus. These scholars, some of whom had been attending the Ege University Cultural Studies Symposium, came from different disciplines but had been adopting a cultural studies approach in their work, which they hoped would gain momentum by this association. It was serendipitous that Professor Tekin Aybaş, a former head-librarian at Middle East Technical University, where some of these scholars had worked or were still working, had become undersecretary at the Ministry of Culture, headed at the time by a MP from Premier Bülent Ecevit's social democrat party. Himself an academic, Professor Aybaş was sufficiently liberal-minded and understanding of his former colleagues to bypass the Ministry's traditional policy of catering to high culture and pro- 
Establishment agendas only, and accepted to allot, even if a modest sum by any standards, funds for the launching of the Group. However, Aybaş soon left because of poor health, and the Group, wishing to remain independent, has been surviving since on the efforts of its members and the financial sacrifice of a few among them.

The Group has met regularly over the last four years to discuss and evaluate the situation in cultural studies in Turkey, publishes a (print and electronic) newsbulletin (see the Group's website at http://www.cstgroup.org), and maintains a moderated electronic discussion group. It has organized meetings among its members to discuss specific books ${ }^{\mathrm{xi}}$ or articles, and talks, open to the public, made by scholars from different universities. One such cluster of talks was on culture itself, a theme which would form a basic building block of discussions on cultural studies. Speakers ranged from Group member Talat Halman ${ }^{\text {xii }}$ the versatile man of letters to İlber Ortayl1 ${ }^{\text {xiii }}$ the prominent Ottoman historian and Şerafettin Turan, professor emeritus of history at Ankara University and a well-known figure, ${ }^{\text {xiv }}$ author of Türk Kültür Tarihi: Türk Kültüründen Türkiye Kültürüne ve Evrenselliğe (History of Turkish Culture: From Turkish Culture to the Culture of Turkey and Universality; 1990), and Hilmi Yavuz the poet-philosopher at present teaching at Bilkent University, author of such books on culture as Felsefe ve Ulusal Kültür (Philosophy and National Culture; 1977), Kültür Üzerine (On Culture; 1987), and Osmanlılık, Kültür, Kimlik (Being Ottoman, Culture and Identity; 1996).

The Group has furthermore organized a seminar at METU in June 2000 with the title, as translated into English, "Introduction to Cultural Studies and an Application: (Im)Migration in Our Culture," ${ }^{\mathrm{xv}}$ and a national cultural studies conference in October 2001 on "Culture and Modernity." The proceedings of the conference, edited by Gönül Pultar, Emine O. İncirlioğlu and Bahattin Akşit, will be published in the fall of 2003. Although small in scale, with around sixty participants, the conference was a first in the country in formalizing on a national platform, in Turkish and as Turkish narrative, cultural studies which had remained until then the domain of scholars whose horizons were directed towards Anglo-centric theories, and who wrote in English, whether they published in Turkey or abroad and even when on Turkish topics. It was evident that some of the paper presenters had not heard of, let alone read, the Anglo-centric gurus - this was the spawning of a brand new paradigm that of course will take a long period of time to mature. Thus, it became just as evident that for anyone to resort to an appraisal of the state of the art in the country, a thorough knowledge of Turkish was imperative. 
The members of the Group are now deploying all their efforts to co-organize with Yüzüncü Y1l University in Van a cultural studies conference in that city on "Cultures of Turkey/Cultures of Turks" ${ }^{\text {"xvi }}$ on 3-5 September 2003, announced as national but become de facto international due to the many participants from outside the country. ${ }^{\text {xvi }}$ The upsurge of abstracts submitted for consideration was overwhelming: it was obvious that there was a greatly-felt need for many scholars to present their work in a platform other than traditional disciplinary contexts, in which this work undoubtedly did not fit.

The inter-university Group set for itself from the beginning an agenda that was meant to seek ways to apply cultural theory to the cultures of Turkey (Turkish, Jewish, Greek, Armenian, Circassian [read Tchechen], Laz, Kurdish and others, such as the Romans), and Turks (in Turkey, in Europe and the West in general, in the former Ottoman territories in the Balkans and the Middle East, and in the former Soviet territories in Central Asia and the Caucasus, and in Iran and China); and if possible to generate new theory and methodology. As can be seen, it spearheaded an ambitious program, but the paradigm inhered the vast scale.

Doing cultural studies in Turkey means first of all studying the cultures, in the plural, of Turkey - the fact that these belong to the various ethnicities living within the territory and so are part of Turkey, aside; too much is enmeshed, and intermingled over the centuries, be it mores, material culture or collective memory - as well as blood: almost everyone is of mixed origin in Turkey, a melting-pot society if ever there was one (on a scale the American melting-pot, even at its most potent, could never have rivaled.) Everyone is, for example, at least one-fourth Albanian, or one-fourth Greek, one-fourth Armenian and one-fourth possibly Hungarian or Pole, with hopefully one-sixteenth pure-blood Turkishness squeezed in-between somewhere, when not pureblooded Bosnian or pure-blooded Albanian in the western regions; and at least one-fourth Kurdish, one-fourth Arabic, when not pure-blooded Kurdish, or pure-blooded Arabic in the eastern regions. ${ }^{\text {xiii }}$ The consciousness is also very much present that the Hittites, as well as the Lydians, Phrygians, and Ionians, did not vanish into thin air but are blood forefathers of the current inhabitants of Turkey, as are Hector and Homer's all other Trojans. ${ }^{\text {xix }}$

One most recent example of the Group's work in the field of ethnicities and cultures of Turkey was organizing the lecture given in Ankara, on the premises of Bilkent University, on 2 April 2003, by a Roman, retired civil servant Mustafa Aksu, who, after relating the story of his integration into the Turkish mainstream, insisted he and his community should be called by their 
proper name "gypsy" — çingene in Turkish_but that the connotation should be made devoid of any political incorrectness. He now spends his time - and his pension—on suing no less than establishments such as the Ministry of Education of the Turkish Republic, to compel them to remove from school textbooks all negative allusions to gypsies. Anthropologist Emine O. İncirlioğlu of Bilkent University, one of the founding members of the Group, is working at present on the Romans and will present a paper on the topic at the Group's September 2003 conference in Van. Kemal Kirişçi of Boğaziçi University, co-author with Gareth M. Winrow of The Kurdish Question and Turkey: An Example of a Trans-state Ethnic Conflict (1997) will also present his latest findings at the Van conference; while Işı1 Baş, also of Boğaziçi University, who heads the graduate Cultural and Critical Studies program of that university, will discuss in her paper at the conference the search for cultural identity in Armenian autobiographical texts, to give just two other instances.

Doing cultural studies in Turkey means also studying the cultures of the Turks in the broadest sense of the word. ${ }^{\mathrm{xx}}$ The Euro-Turkish diaspora and its problems beg for attention; imbricating questions of immigration and deterritorialization, as well as issues related to the fluidity of identity, which themselves open up an infinite number of avenues of study. In another vein, the dismantling of Yugoslavia, and the ever-growing repercussions of the peace that ended all peace in the Middle East, as David Fromkin put it, ${ }^{\mathrm{xxi}}$ have introduced issues of national and ethnic identity formation that require a re-examination of residual Turkish culture both in the Balkans and in the territories T. E. Lawrence so infamously helped carve from the Ottomans. ${ }^{\text {xii }}$ The demise of the Soviet Union has on the other hand brought to the fore the cultural and ethnic ties that bind the Turkic peoples, as they are labeled, and the Turks of Turkey, introducing at once just as compelling issues of nation-building projects and renegotiations of identity. Azerbaijan in the Caucasus; and Kazakhstan, Kirghizstan, Turkmenistan, and Uzbekistan, made nominal republics by the Soviet regime which decimated thus the vast territory of West Turkestan, a unitary guberniya in Central Asia during the Czarist regime, are now independent nation-states. They now find themselves confronted with problems they would not have dared to envisage before the fall of the Berlin Wall. In the lecture she delivered at METU within the Group for Cultural Studies series, entitled "The Search for Cultural Identity in Northern and Southern Azerbaijans under Russian and Iranian Hegemonies," Seriye Genceliyeva Tamer 
(Bilkent University), herself a native of northern Azerbaijan, gave a poignant compte rendu of the plight of a divided nation and the issues of identity and culture this engenders.

On the other hand, even more immediate and urgent issues of cultural identity are being experienced by those communities of Turks still under Russian hegemony, and especially the Turks in the Volga-Ural region (the territory between the Volga river and the Ural mountains) of the Russian Federation, divided at present as the merely autonomous republics of Tchuvachstan, Tatarstan and Bashkiria. As the Putin regime forbade the republic of Tatarstan the switch to the Latin alphabet, which was to start with the beginning of the school year in the fall of 2002, the alphabet has become a trope for cultural and national identity in that region. If cultural studies means the study of the interplay of power and politics, cultural studies is particularly relevant for the study of the cultures of the Turks of the Volga-Ural region. The tortuous relationship with Moscow and the debates on the use of a "national" alphabet as a marker of identity, as well as the various nation-building projects involving different and incompatible theories of ethnic belonging, such as conceptualizing the people(s) of the region as Bulgars (making them autochthonous but narrowing their patria to the territory of the ninth-century Bulgar Khanate), Kazanlis or Tatars (putatively allowing them the whole of the commonwealth of the Golden Horde state, but underscoring their foreignness to the soil, as descendants of the Mongol Tatar tribe), that are being evolved at present, ${ }^{\text {xiii }}$ constitute an absorbing topic for the student of cultural studies. They herald moreover a new turn as former names such as Alexandre Benningsen and Hélène Carrère d'Encausse, scholars who did Soviet studies work on the region during the Cold War, are now giving way to new names such as Uli Schamiloglu of the University of WisconsinMadison, himself a US-born ethnic Turk of the Volga-Ural region.

The emergence of the Group has therefore introduced what amounts to a new discourse in cultural studies parlance in Turkey. New names of theoreticians and critics have been introduced into the pantheon of cultural thinkers. When Gönül Pultar, elected Chair of the Group in its second meeting in 1999, made her inaugural speech at the (Im)Migration conference at Middle East Technical University, in June 2000 - alongside names such as Benedict Anderson, Homi Bhabha, Eric Hobsbawm, Edward Said, and Raymond Williams, which she mentioned-she introduced the names and ideas of the likes of Bozkurt Güvenç, author of Türk Kimliği: Kültür Tarihinin Kaynaklarl (Turkish Identity: Sources of Cultural History; 1993); Suat Sinanoğlu, author of Türk Hümanizmi (Turkish Humanism; 1980); and Hilmi Ziya Ülken, author of İslam 
Düşüncesi (Islamic Thought; 1946) and at her inaugural speech at the October 2001 conference of the Group in Kemer (Antalya) on Culture and Modernity, names such as Nilüfer Göle, author of Modern Mahrem (1992; translated as The Forbidden Modern, 1996) and Şerif Mardin. ${ }^{\text {xiv }}$ All of these scholars may have considered themselves purely anthropologists, sociologists, and so forth, as they wrote at a time when interdisciplinarity had not attained the proportions of its present currency. Yet, by its very nature, their work and the approach that informs it constitute the foundations of the paradigm.

As can be seen, by complicating and problematizing issues not taken up elsewhere, the Group has both underscored and begun to complement the caveats of the formal programs. It should be acknowledged that Türk Kültürünü Araştırma Enstitüsü (Institute for Research in/on Turkish Culture) based in Ankara, now defunct all but in name, did much valuable work during the Cold War period that falls within cultural studies, although, understandably, most of it is purely descriptive. In fact, like M. Jourdain who did not know he was doing prose, there is cultural studies work already done and being done on cultures of Turkey and of Turks, both within the country and abroad, which is not so acknowledged. ${ }^{\mathrm{xxv}}$ One of the objectives of the Group is, if possible, to attempt to coordinate these efforts.

It is a fact that there is a lot to be done in order to establish cultural studies properly in Turkey and that there are many interesting trajectories cultural studies in this country could take. However, the major goal for those involved remains, as already stated above, to generate original theorization, and also to provide a new focus that will counterbalance the identity crises articulated by many. However, this is a daunting project. On the one hand, the social rank of the Turkish Gastarbeiter in the EU is, as German journalist Günter Wallraff has it, Ganz Unten (The underdog; 1985), a positionality that in the eyes of the majority in the West extends not only to the numerous Turkish white-collar professionals actually thriving in the EU, but also to the whole of Turkish society, with Turks as "inferior element" constituting excellent material for Orientalism - a state of affairs that leads Turks often to lapse into thinking of themselves as subalterns of the global village. On the other hand, former subalterns of the Ottoman Empire ${ }^{\mathrm{xxvi}}$ most obligingly remind the world - and the Turks - that until less than a century ago, Turks had been a hegemonic power for over half a millennium. Then one realizes that that is the reason, rather than having been inferior in any way, that Turks have been victimized by Orientalism. No West-based theory offers any explication de texte for this paradox, and many Turks live in this 
schizoid condition. This situation, therefore, presents an incredible, and immense, challenge for Turkish cultural studies. In fact, this is just one of many quite interesting and complex problematics that need to be addressed by cultural studies in Turkey.

\section{ISSUES TO BE TACKLED:}

The resistance of the gate-keeping old guard academics in humanities and social sciences to the cultural studies tenor was already mentioned. This condition naturally generates an understandable reticence on the part of aspiring young scholars who value academic promotion over all else. Thus, the system continues to reproduce itself, making it difficult for cultural studies to permeate and develop. It is telling that the programs discussed so far have been established in four universities only, out of a total of eighty in the whole of the country; with two programs in two state universities of international stature whose administrators feel sufficiently secure to introduce novelty, and two in private universities that have been founded only recently, with one avowedly shunning the traditional department system. However, it may be advanced that such resistance and reticence have been observed in many emerging areas of learning throughout the history of science in all regions of the world where it has flourished. Thus, in this section we will discuss those issues that are specific to the current instruction and practice of cultural studies in Turkey. For the sake of convenience, we divide these into two, as the local and the global, with subdivisions among them.

\section{The Local}

What we would like to label the local is a Weltanschaung that inheres a total lack of the cultural studies tenor. What we have in mind primarily is an attitude that considers any mention of ethnicity as part of a political agenda pure and simple. Of course this assumption works both ways. On the one hand, cultural studies topics (and its discourse) are time and again unscrupulously exploited by those who would like to promote their own political agendas, emitting texts that are pure jeremiads devoid of any sense of scholarship or academic analysis. As cultural studies is said to have evolved out of and replaced Marxist studies (at least in the UK), this impulse may be said to be repeating the good old Marxist discourse of the Cold War period. Yet, when all is said and done, it is the worst enemy of cultural studies, since by appropriating the 
language of cultural studies it smears it, and deprives the paradigm, already not taken seriously by traditionalists because of its interdisciplinary nature, of much-needed sound scholarly reputation. On the other hand, there are many who consider any exercise in cultural studies to be inherently political, subversive to the point of breaking prevalent laws, without stopping to perceive the scholarship and/or academic analysis it contains. On the defensive against the former group, their fight is with them, yet these also turn out to be inimical to cultural studies, as they attempt to prevent the realization of any work they (often quite wrongly) perceive to be politically nefarious. To be counted among them are the Kemalists of olden times today labeled "dinosaurs" who are unable to distinguish that the world of the twenty-first century is a far cry from that of the 1920s when they and their forebears most courageously fought for and founded a nation-state. The ideology they both forged and espoused, crystallized over the years of instruction/indoctrination in schools throughout the country, today hampers their grasp of new dynamics, such as the existence of multicultural societies (viz. the Kurdish discourse) or the fact that the (Ottoman) Empire has the cheek to write back (viz. the Armenian discourse) - while they themselves are accused of ignoring the Turkic "blood brothers," as well as relegating to oblivion the colossal legacy of the Ottoman centuries. The latter have become more actual than during their existence proper, due to the latest developments in the Balkans and the Middle East: anyone wishing to make sense of the recent carnage in Bosnia or the US-UK occupation of Iraq finds him/herself obliged to go to the roots of the matter, that perforce involves studying Ottoman history.

Which brings us to the second issue created by those unlettered in cultural studies. For many, cultural studies signifies the study of culture, Kultur in the good old sense, when it meant high culture only. It must be said that the culture(s) of Turkey and Turks is (are) of mammoth proportions, whether this patrimony is seen as pertaining to Turkey, with Homer and Saint Paul, among others, native to the land; to the past of the present citizens of Turkey, with ancestral, familial, and affective bonds to lands occupied by successor states to the Ottoman EmpireMustafa Kemal Atatürk, the victorious commander who became the first president was himself born in what is now Greece; or as that of Turks as a people issued from Central Asia and dispersed to almost the four corners of the world — one of the most well-known of such migrants being the late Rudolf Nureyev. That this has been a continuous culture is best seen in the case of literary output. As a recent call for papers for a literary studies journal has it: 
The literature of the Turks is among the oldest of living literatures. In nearly a millennium and a half, it has been alive in many continents and regions, expressing itself in a diversity of languages and scripts, and remaining receptive to external influences as well as maintaining its intrinsic impetus for renewal. From Central Asia to Anatolia and beyond, it has served as a faithful mirror of Turkish society and culture ... [The journal] hopes to present to the . . . world new critical perspectives on the fifteen centuries of the corpus of literary works produced in the Turkish-speaking world. (1999 flyer for Journal of Turkish Literature to be published by Bilkent University.)

With every generation offering as well as requiring its own interpretation, it is a fact that a formidable task is awaiting traditional students of culture and these mistake the appellation "cultural studies" for their own occupation. The steering committee of the September 2003 conference of the Group for Cultural Studies and Yüzüncü Y1l University heart-rendingly had to reject many an abstract, deserving in its own right, that possessed no sensitivity whatsoever to cultural studies. In sum, that the two types of scholarship have different vocations is not apparent to many who are gatekeepers, decision-makers and purse-holders, to the detriment of the proselytes of cultural studies.

That the pursuit of cultural studies is being overshadowed or unknowingly impeded by the traditional study of culture is a matter of crucial importance, and perhaps such a brief treatment does not do justice to it. We must yet move on to what we have labeled the global issue, involving intellectuals and scholars very much cognizant of the dynamics of cultural studies, creating nevertheless another sort of problem.

\section{The Global}

We have named the global the issue created by those scholars and intellectuals quite knowledgeable about cultural studies who work on Turkish cultural studies - to disparage the subject matter itself, in other words to disparage the Turks, Turkey, the cultures of Turks and the cultures of Turkey. Presenting papers and publishing in English, in international venues and publications, they nip in the bud a burgeoning field, namely Turkish cultural studies, already rendered sufficiently fragile by the agents we have labeled "local." These may also be called "neo-Orientalists," and may be divided as the foreign-born and the Turkey-born. We would like to advance that what they are doing runs counter to the very spirit of cultural studies. 
"Modernization discourse ordered the world and its knowledges according to a clear hierarchy," writes Arif Dirlik. "EuroAmerica [sic.] stood at the pinnacle of the hierarchy, showing the rest of humanity its future." ${ }^{x x v i i}$ This is the maxim on which the global agents base the premise of their Turkish cultural studies discourse. The gist of their message is that Turks, under whatever guise one chooses to apprehend them, Turks of Turkey, Euro-Turks, Turkics, etc., may be objects of study and analysis, and food for thought, so to speak, with their deeds, cultures in the anthropological sense, and any other social institutions they may possess. But being at the wrong end of the "hierarchy," Turks may not themselves be entitled to be considered as "subjects" worthy of the appellation, and be capable of any scientific scholarship. If Turks exert any efforts that by objective standards should put them on par with the EuroAmericans, that is not a genuine, authentic, or what have you, gesture, but imitation, mimicry, singeing, simulation, appropriation, translation pure and simple, the creation of an ersatz culture.

This is a stance that goes back to a long-standing tradition. Nevertheless, as the presentday "global" agents are considered, it is interesting to note that it is not so much academics formed in traditional Turkish studies disciplines such as Turkish history, Turkish literature etc. that one finds the stance - although many among them do also adopt it, albeit in more nuanced tones, no doubt about that. The traditional Turkish studies scholars are nevertheless well aware that, as mentioned above, the legacy of Turkish culture, whether high culture, material culture, etc., is of too vast proportions to advance in credible terms any such proposition. The dimensions of the patrimony do not allow moreover these scholars any occasion to formulate such idle propositions, so much material there is to attend to, study and work on. These are also alive to the fact that, as the call for papers quoted above puts it, Turkish culture has all throughout the centuries been "receptive to external influences as well as maintaining its intrinsic impetus ..." How can one imagine Turkish poetry without its Persian element?

It is rather academics who arrive in the country, usually to teach matters Western, and untainted by any intelligence whatsoever on matters Turkish, who are the "global" agents. Not having lived in the country long enough to learn its ways, not caring enough about its people and systems to wish to invest the time and effort to learn its language and customs which are the very basic keys to understanding a culture, these neophytes depict an ill-disguised attitude of neocolonialism by publishing about the country, using its resources as raw material for furthering their own academic careers. 
Cocooned in the cloistered campuses of private universities, cut off from the real people spatially, linguistically and ideologically, using isolated and uninformed non-natives like themselves as their informants, and writing from an unabashed stance of neo-colonialist discourse, these experts reenact an old cliché: the blind leading the blind into Plato's cave where they are unable even to discern and interpret the pathetic flicker of light on the walls of their secluded caves.

Egging them on are native experts who build careers on the same premise, as diligent and docile pupils telling on their classmates. It is a fact that, as both authors have had ample occasion to observe, acceptance on the part of Western peers more often than not depends on the degree of submissiveness to Western norms that include the Orientalist approach of considering matters pertaining to Turks as inferior. Thus, a not uncommon pre-requisite for being acknowledged as a scholar or published in the West is the adoption of this stance. So native Turkish scholars do sometimes join the foreigners both abroad and in Turkey in observing Turkish culture with the Western neo-Orientalist lens, thereby ignoring, or refusing to acknowledge the existent truly Turkish discourse.

\section{CONCLUSION}

Cultural studies in theory and in practice is an ideological and methodological minefield no matter where it is established, engaged and practiced, and the case in Turkey is no different. sensitive to the overwhelmingly fast-changing agendas that relate to globalization, realignment in balances of power and the new world order. It seems that no academic, intellectual, or institution - in fact, no person — pursuing a meaningful interaction with the Brave New World can afford to ignore the work that is being done in cultural studies on any level: to resist the quick-fix solutions, to temper creativity with eclecticism, and to understand and empathize with the culture when analyzing it. Scholars and intellectuals often confess to leading double lives: one of discussing ideology as if it were not related to real life issues, in a vacuum, safe and relegated exclusively to books on theory. Their other lives are structured around ossified and no-longerrelevant solutions to everyday issues. It takes a brave heart, it seems, to take on the probable social and academic ostracization that would result from tackling red-hot issues with new insight. 
This means mixing the textbook with real-life issues of ideology, being ready and willing to deal with current problems with novel and perhaps alternative solutions.

Cultural studies is alive and well in Turkey. It has taken root in the fertile, ancient soil, prospered and been institutionalized. The institutions that have made cultural studies a part of their curricula are cognizant of the challenges ahead, both inside the classroom (methodology, etc.), and out (resistance from the old ideologues, etc.). Perhaps the real challenge lies in being sensitive to the overwhelmingly fast-changing agendas that relate to globalization, realignment in balances of power and the new world order. It seems that no academic, intellectual, or institution - in fact, no person - pursuing a meaningful interaction with the Brave New World can afford to ignore the work that is being done in cultural studies on any level: to resist the quick-fix solutions, to temper creativity with eclecticism, and to understand and empathize with the culture when analyzing it.

\section{NOTES}

\footnotetext{
${ }^{\mathrm{i}}$ See her Schwarzer Tee mit Drei Stück Zucker (Black Tea with Three Lumps of Sugar; 1991); Die Frau mit Bart (The Woman with [a] Beard; 1994); and Es Wird Diamanten Regen von Himmel (Diamonds Will Rain from the Sky; 1999).

${ }^{\text {ii }}$ See her Das Leben ist eine Karawanserei, Hat Zwei Türen, Aus Einer Kam ich Rein, Aus Der Anderen Ging Ich Raus (1992), translated into English as Life is a Caravanserai: Has Two Doors, I came in One, I Went Out the Other (2000); Mutterzunge: Erzählunge (1998), translated into English as Mother Tongue (1994); and Die Brücke von Goldenen Horn (The Golden Horn Bridge; 1998).

iii See e.g. Azade Seyhan, Writing Outside the Nation (2001) for an intelligent discussion of the authors mentioned above.

iv The second language of Turkish intellectuals, besides Arabic and Persian, was for a very long time French. The U.S.I.S. especially, in collaboration with the Fulbright commission, had to spend billions of dollars during the Cold War, in this country with common borders with the Soviet Union, to reverse the trend and establish English as the lingua franca of the Turkish intelligentsia.

"See Laurence Raw, "Perspectives on British Studies in Turkish Universities" for a discussion of the establishment in Turkey of "British Studies," an "interdisciplinary approach to contemporary Britain," in practice British Cultural Studies, designed to "attract students away from American Studies," which the British Council saw as being American Cultural Studies. David Punter confirms Raw's statements when he writes that, "British Cultural Studies, I take it, is a discipline which is designed - or is being designed in practice - specifically for teaching outside Britain," then indicates that "British Cultural Studies and the agencies which provide and foster it are
} 
already elements in a map, a map which also includes other, nationally diverse, agencies which are in some sense providing a parallel service - the United states Information Service, the Goethe Institute, and so forth" $(65,67)$.

${ }^{v i}$ Selves at Home, Selves in Exile: Stories of Emplacement and Displacement (2003), edited by Ayşe Lahur Kırtunç et al., is the most recent volume.

vii Another outcome was the publication of Ĭgnem Ipliğim, Diktiğim Kimliğim (Fabrics and Fabrications; 2000) by Ayşe Lahur Kırtunç, a member of the department, and its Chair at present (2000- ) in which she analyzes products of popular culture, visual arts, material culture and literature to illustrate how labor history, sociology, anthropology, women's studies and literary criticism can be employed to shed light on various aspects of culture.

viii See Hülya Adak, "Sabancı Üniversitesi 'Kültürel Etüdler' Programı (The Sabancı University "Cultural Studies" Program)" for a brief overview of the program and the seminars it has been organizing, by a member of its faculty. Another member of faculty of the program, Annedith Schneider, discusses at length this new program, in an article that is understandably laudatory of it, yet somewhat hazy, to say the least, on the general Turkish situation presented in her introduction (see her "The Institutional Revolutionary Major: Questions and Contradictions on the Way to Designing a Cultural Studies Program in a New Turkish University").

ix See Işı1 Baş, "Boğaziçi Üniversitesi Eleştiri ve Kültür Araştırmaları Yüksek Lisans Programı 2002-2003 Yılında Öğrenime Başladı (The Boğaziçi University Critical and Cultural Studies Program Started in the Academic Year 2002-2003)," for a brief overview of the program, by its coordinator.

${ }^{x}$ These are Bahattin Akşit (METU), Çiğdem Balım (University of Manchester), Mutlu Binark (Gazi University, Ankara), Gülriz Büken (Bilkent University, Ankara), Talat Halman (Bilkent University), Ayşe Lahur Kırtunç (Ege University), Gönül Pultar (Bilkent University), Laurence Raw (Başkent University), Himmet Umunç (Hacettepe University, Ankara), and Yıldırım Yavuz (METU).

${ }^{x i}$ One such book was Istanbul: Küresel ile Yerel Arasinda (1999, the Turkish translation of Istanbul: Between the Global and the Local; 1999).

xii A poet in his own right, Professor Halman has made translations of poetry from English and Persian into Turkish, and of both poetry and prose from Turkish to English; has edited, besides collections of his own journalistic writings, various collections of selections from Turkish literature; and co-authored Mevlana Celaleddin Rumi and the Whirling Dervishes (1983). Some of his translations are: A Dot on the Map: Selected Stories and Poems by Sait Faik (1983); Yunus Emre: Selected Poems (1993); and, translated with Ruth Christie and Richard MacKane, Beyond the Walls: Selected Poems of Nazım Hikmet (2002). He is the editor of Turkey: From Empire to Nation (1973); Modern Turkish Drama: An Anthology of Plays in Translation (1976); and Contemporary Turkish Literature: Fiction and Poetry (1982).

xiii Imparatorluğun En Uzun Yüzyll (The Longest Century of the Empire; 1983); Studies on Ottoman Transformation (1994); Osmanl Imparatorluğu'nda Iktisadi ve Sosyal Değişim (Economic and Social Change in the Ottoman Empire; 2000); Osmanlı Toplumunda Aile (Family in Ottoman Society; 2000); and Gelenekten Geleceğe (From Tradition to the Future; 2001) are some of the titles of his numerous books.

${ }^{\text {xiv }}$ A left-leaning intellectual, Professor Turan served as undersecretary at the Ministry of Culture, and as President of Türk Dil Kurumu (Turkish Language Institute) and later of Dil Derneği (Language Society) when that association was formed to protest the Türk Dil Kurumu being entrusted in rightist hands. 
${ }^{\mathrm{xv}}$ The texts of some of the presentations are on the website of the Group.

${ }^{x v i}$ The proceedings of the conference will be edited by Tahire Erman (Bilkent University), Gönül Pultar and Dikmen Yakalı (Birmingham University).

xvii The next conference of the Group, entitled "Identity and Culture," and co-organized with

Boğaziçi University, will take place in Istanbul on 14-17 June 2005.

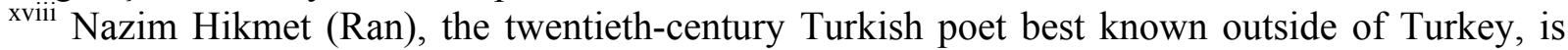
ethnically of Polish descent - and was born in Thessaloniki, in what is now Greece. Of the two best lyrical poets of the Turkish language in the twentieth-century, Ahmet Haşim is ethnically an Arab from Baghdad; while Yahya Kemal Beyatl, an ethnic Turk, was born in Skopje, in what is now Macedonia. The twentieth-century novelist best known outside of Turkey, Yaşar Kemal Gökçeli, is an ethnic Kurd. The early works of this author who first earned his bread as an itinerant story-teller (he is probably one of the last of the practitioners of this dying profession) were transcriptions of folk legends floating in his native Southern Anatolia; their worth lies more than anything else in his use of the Turkish language, with lyrical passages consisting of pagelong sentences.

${ }^{x i x}$ See the feature film Hititler (The Hittites; 2003), directed/produced by Tolga Örnek.

${ }^{\mathrm{xx}}$ Renat Taziev, Ronald Hatto and François Zdanowicz call Turks a mega-ethnicité in "La Turcophonie: Naissance d'un Nouveau Monde? (The Turcophony: Birth of a New World?)."

${ }^{x x i}$ A Peace to End All Peace: Creating the Modern Middle East (1989).

${ }^{x x i i}$ He himself relates it with superb aplomb in his Seven Pillars of Wisdom: A Triumph (19221926).

xxiii These issues were the themes of the papers presented at the conference on "Tatars and Tatarstan" organized at Marmara University (Istanbul) on 27 February 2003, especially that of Timour Kozyrev (Boğaziçi University), entitled "Tatar Milli Kimliğinin Oluşumu (Formation of Tatar National Identity)."

${ }^{\text {xxiv }}$ See, besides the oeuvre in Turkish, The Genesis of Young Ottoman Thought: A Study in the Modernization of Turkish Political Ideas (1962); and Religion and Social Change in Modern Turkey: The Case of Bediüzzaman Said Nursi (1989); and as editor, Cultural Transitions in the Middle East (1994); and Religion, Society, and Modernity in Turkey (2003).

${ }^{\mathrm{xxv}}$ To illustrate, a panel entitled "Turkish Culture between Ottomans and Turks," held at the 4-6 December 1998 meeting of the Middle East Studies Association of North America (MESA) in Chicago, IL, was a cultural studies exercise, not so advertized. Besides two Turkish scholars, Walter Andrews (University of Washington) presented a paper entitled "Stepping Aside: Ottoman Literature in Modern Turkey," in which he proposed to abandon the clichéd binaries modern-traditional, etc. in assessing Ottoman literature, and adopt a Deleuzian-Guattarian reading. Fragments of Culture: The Everyday of Modern Turkey (2002), edited by Deniz Kandiyoti and Ayşe Saktanber, two Turkish scholars, is also another such work.

${ }^{x x v i}$ The Armenians are the most articulate in this subject but Serbs and Croatians, who destroyed much of Ottoman-Turkish cultural patrimony in Bosnia, have been just as "obliging," and in fact turned out to be, with the ethnic cleansing they resorted to, much more homicidal than the Armenians' terrorist organization ASALA.

xxvii "Reconfiguring Modernity: From Modernization to Globalization."

\section{REFERENCES}


Adak, Hülya. "Sabancı Üniversitesi 'Kültürel Etüdler' Programı (The Sabancı University 'Cultural Studies' Program)." bülten (newsbulletin of the Group for Cultural Studies in Turkey). No. 9, January 2003, 6.

Andrews, Walter. "Stepping Aside: Ottoman Literature in Modern Turkey." Paper presented at the panel entitled "Turkish Culture between Ottomans and Turks," at the 4-6 December 1998 meeting of the Middle East Studies Association of North America (MESA) in Chicago, IL.

Baş, Iş11. "Boğaziçi Üniversitesi Eleştiri ve Kültür Araştırmaları Yüksek Lisans Programı 20022003 Yılında Öğrenime Başladı (The Boğaziçi University Critical and Cultural Studies Program Started in the Academic Year 2002-2003)." bülten (newsbulletin of the Group for Cultural Studies in Turkey). No. 9, January 2003, 7.

Demirkan, Renan. Schwarzer Tee mit Drei Stück Zucker (Black Tea with Three Lumps of Sugar). Köln: Kiepenheuer \& Witsch, 1991.

----. Die Frau mit Bart (The Woman with [a] Beard). Köln: Kiepenheuer \& Witsch, 1994.

-----. Es Wird Diamanten Regen von Himmel ((Diamonds Will Rain from the Sky). Köln: Kiepenheuer \& Witsch, 1999.

Dirlik, Arif. "Reconfiguring Modernity: From Modernization to Globalization." http://www.sidint.org/programmes/politicsplace/politicsDirlik.PDF, accessed 19 June 2003.

Faik, Sait. A Dot on the Map: Selected Stories and Poems by Sait Faik. Trans. Talat Halman with editorial assistance by Jayne L. Warner, with an introduction by the translator. Bloomington, IN: Indiana University Turkish Studies Publications, 1983.

Fromkin, David. A Peace to End All Peace: Creating the Modern Middle East. London: A. Deutsch, 1989.

Göle, Nilüfer. The Forbidden Modern: Civilization and Veiling. Ann Arbor, MI: University of Michigan Press, 1996.

Güvenç, Bozkurt. Türk Kimliği: Kültür Tarihinin Kaynakları (Turkish Identity: Sources of Cultural History). Ankara: Kültür Bakanlığı Yayınları, 1993.

Halman, Talat S., ed. Turkey: From Empire to Nation. Jamaica, NY: St. John's University, 1973.

-----, ed. Modern Turkish Drama: An Anthology of Plays in Translation, with an introduction by the editor. Minneapolis, MN: Bibliotheca Islamica, 1976.

-----, ed. Contemporary Turkish Literature: Fiction and Poetry, with an introduction by the editor. Rutherford, NJ: Farleigh Dickinson University Press, 1982.

Halman, Talat S. and Metin And. Mevlana Celaleddin Rumi and the Whirling Dervishes. Istanbul: Dost Yayınları, 1983.

Hikmet, Nazım. Beyond the Walls: Selected Poems of Nazım Hikmet. Trans. Ruth Christie, Talat Halman and Richard MacKane. London: Anvil Press Poetry, 2002.

Kandiyoti, Deniz and Ayşe Saktanber. Fragments of Culture: The Everyday of Modern Turkey. New Brunswick, NJ: Rutgers University Press, 2002.

Keyder, Çağlar, ed. Istanbul: Between the Global and the Local. Lanham, MD: Rowman \& Littlefield, 1999.

-----, ed. Istanbul: Küresel ile Yerel Arasında (Istanbul: Between the Global and the Local). Çev. (Trans.). Sungur Savran. Istanbul: Metis, 1999.

Kırtunç, Ayşe Lahur. İğnem İpliğim, Diktiğim Kimliğim (Fabrics and Fabrications). Izmir: Ege University Publication of the Faculty of Letters, 2000.

Kırtunç, Ayşe Lahur et al. Selves at Home, Selves in Exile: Stories of Emplacement and 
Displacement. Izmir: Ege University Publication of the Faculty of Letters, 2003.

Kirişçi, Kemal and Gareth M. Winrow. The Kurdish Question and Turkey: An Example of a Trans-state Ethnic Conflict. Portland, OR: Frank Cass and Co., Ltd, 1997.

Kozyrev, Timour. "Tatar Milli Kimliğinin Oluşumu (Formation of Tatar National Identity)."

Paper presented at the conference on "Tatars and Tatarstan" organized at Marmara

University (Istanbul) on 27 February 2003.

http://www.symposium27february2003.info/zila/presentation/t milkim.htm, accessed 19 June 2003.

Lawrence, T. E. Seven Pillars of Wisdom: A Triumph. 1922 and 1926 texts. Fordingbridge, UK: Castle Hill, 1997.

Mardin, SSerif. The Genesis of Young Ottoman Thought: A Study in the Modernization of Turkish Political Ideas. Princeton, NJ: Princeton University Press, 1962.

-----. Religion and Social Change in Modern Turkey: The Case of Bediüzzaman Said Nursi. Albany, NY: State University of New York, 1989.

-----, ed. Cultural Transitions in the Middle East. Leiden and New York: E. J. Brill, 1994.

-----, ed. Religion, Society, and Modernity in Turkey. Syracuse, NY: Syracuse University Press, 2003.

Ortaylı, İlber. Imparatorluğun En Uzun Yüzyılı (The Longest Century of the Empire). Istanbul: Hil Yayınlar1, 1983.

-----. Studies on Ottoman Transformation. Istanbul: The Isis Press, 1994.

-----. Osmanlı Imparatorluğu'nda Iktisadi ve Sosyal Değişim (Economic and Social Change in the Ottoman Empire). Ankara: Turhan Kitabevi, 2000.

----. Osmanlı Toplumunda Aile (Family in Ottoman Society). Istanbul: Pan, 2000.

-----. Gelenekten Geleceğe (From Tradition to the Future). 5th Ed. Istanbul: Ufuk Kitaplar1, 2001.

Özdamar, Emine Sevgi. Das Leben ist eine Karawanserei, Hat Zwei Türen, Aus Einer Kam ich Rein, Aus Der Anderen Ging Ich Raus (Life is a Caravanserai: Has Two Doors, I came in One, I Went Out the Other). Köln: Kiepenheuer \& Witsch, 1992.

----. Life is a Caravanserai: Has Two Doors, I came in One, I Went Out the Other. Trans. Luise von Flotow. London: Middlesex University Press, 2000;

-----. Mutterzunge: Erzählunge (Mother Tongue: Stories). Köln: Kiepenheuer und Witsch, 1998.

-----. Mother Tongue. Trans. Craig Thomas and Alberto Manguel. Toronto: Coach House Press, 1994.

-----. Die Brücke von Goldenen Horn (The Golden Horn Bridge). Köln: Kiepenheuer \& Witsch, 1998.

Pultar, Gönül, Emine O. Incirlioğlu and Bahattin Akşit, der. (eds.). Kültür ve Modernite (Culture and Modernity). Istanbul: (co-published by Tetragon Press and Group for Cultural Studies in Turkey, 2003.

Punter, David. "Fictional Maps of Britain." Studying British Cultures. Ed. Susan Basnett. London: Routledge, 1997, 65-80.

Raw, Laurence. "Perspectives on British Studies in Turkish Universities." http://britishcouncil.org.tr/education/bcs/articles/turobj.htm, accessed 10 March 2003.

Said, Edward. Orientalism: Western Conceptions of the Orient. Harmondsworth, UK and New York: Penguin, 1978.

Schneider, Annedith. "The Institutional Revolutionary Major: Questions and Contradictions on the Way to Designing a Cultural Studies Program in a New Turkish University." International Journal of Cultural Studies. Vol 5(4): 393-404. 
Seyhan, Azade. Writing Outside the Nation. Princeton, NJ: Princeton University Press, 2001. Sinanoğlu, Suat. Türk Hümanizmi (Turkish Humanism). Ankara: Türk Tarih Kurumu Yayınları, 1980.

Tamer, Seriye Genceliyeva. "Rus ve Fars Egemenliği Altında Kuzey ve Güney Azerbeycan'da Kültürel Kimlik Arayışları (The Search for Cultural Identity in Northern and Southern Azerbaidjans under Russian and Iranian Hegemonies)." Lecture delivered at Middle Technical University (Ankara), within the series organized by the Group for Cultural Studies, on 5 March 2003.

Taziev, Renat, Ronald Hatto et François Zdanowicz. "La Turcophonie: Naissance d'un Nouveau Monde? (The Turcophony: Birth of a New World?)." Dire. Vol 5(2):26-27.

Turan, Şerafettin. Türk Kültür Tarihi: Türk Kültüründen Türkiye Kültürüne ve Evrenselliğe (History of Turkish Culture: From Turkish Culture to the Culture of Turkey and Universality). Ankara: Bilgi Yayınevi, 1990.

Ülken, Hilmi Ziya, İslam Düşüncesi: Türk Düşünce Tarihi Araştırmalarına Giriş (Islamic Thought: An Introduction to the History of Turkish Thought). 1946. Ankara: Ülken Yayınları, 1995.

Walraff, Günter, Ganz Unten. Köln: Kiepenheur und Witsch, 1985.

Yavuz, Hilmi. Felsefe ve Ulusal Kültür (Philosophy and National Culture). Ankara: Bilgi Yayınevi, 1977.

-----. Kültür Üzerine (On Culture). İstanbul: Bağlam Yayınları, 1987.

-----. Osmanlılık, Kültür, Kimlik (Being Ottoman, Culture and Identity). İstanbul: Boyut Kitapları, 1996.

Yunus Emre. Yunus Emre: Selected Poems. Trans. Talat Halman. 2nd ed. Ankara: Turkish Republic Ministry of Culture Publications, 1993.

http://css.ege.edu.tr

http://www.bilgi.edu.tr/graduate/MAindex.htm\#10

http://www.boun.edu.tr/graduate/index tur.html

http://www.cstgroup.org

http://www.metu.edu.tr/home/wwwsbe/MCS/info.htm

http://www.sabanciuniv.edu.tr/english/index1.html 